\title{
Protein based condiment cube mold
}

\begin{abstract}
African locust bean (Parkia biglobosa) seed was fermented to a protein based soup and stew additive. Fermentation was carried out for three days after which the fermented seeds were oven dried at a very low temperature for four days. Dried fermented seed were powdered and compressed using the fabricated mold into cubes
\end{abstract}

Keywords: locust beans, fermentation, mold, Parkia biglobosa
Volume 3 Issue 4 - 2019

\author{
Modupe Elizabeth Ojewumi, Bolaji Adeoye \\ Adenuga \\ Chemical Engineering Department, Covenant University, Nigeria
}

Correspondence: Modupe Elizabeth Ojewumi, Chemical Engineering Department, Covenant University, P.M.B I023, Canaan Land, Sango, Ogun State, Nigeria,

Email modupe.ojewumi@covenantuniversity.edu.ng

Received: June 27, 2019 | Published: August 09, 2019

\section{Introduction}

African Locust bean with botanical name Parkia biglobosa is a leguminous plant found in the Savannah region of Nigeria. The botanical name Parkia biglobosa was given to it by Robert Brown, a Scottish botanist in $1826 .{ }^{1}$ He described the tree as genus of flowering plants in the legume group which belongs to the sub-family Mimosoideae and Leguminosae. ${ }^{2-5}$ Parkia biglobosa (African locust bean seeds) is a perennial deciduous tree that grows from $7 \mathrm{~m}$ to 20 meters high. ${ }^{3,6,7}$

Apart from fermented Parkia biglobosa seeds (Iru) serving as a rich source of plant protein to man with low cost, it also serves as good source of protein for animal feeds, chick and fish (Livestock). ${ }^{89}$ Apart from these nutritional values, fermented African locust bean seeds provide dietary fiber, energy, minerals and vitamins such as Vitamin B, riboflavin and Vitamin A. ${ }^{8}$ It also improves sensory properties of foods which includes the organoleptic characteristics (appearance, aroma and flavor).$^{10}$ Fermentation is the biological conversion of complex substrate such as starch or sugar into simple compounds by microorganisms. ${ }^{11}$ It can also be defined as the production of energy from food without using oxygen. ${ }^{12}$

So many work has been done on the processing of African locust bean seed into a protein based condiment using various methods. Various mathematical modelling and optimization principles have been employed to compare the experimental result with modelling or optimised result. ${ }^{13-15}$

\section{Materials and methods}

\section{Raw materials}

African locust bean seeds were bought from open market at the $6^{\circ} 40^{\prime} 48.47$ 'N,3 9'19.6" E. The starter cultures used were freshly prepared in the Microbiology laboratory, Covenant University, Ota, Nigeria using method. ${ }^{16-20}$

\section{Preparation of seed}

The raw seed were processed according to ${ }^{1,13,21,22}$ Figure $1 \&$ Figure 2.

\section{Fabrication of mold}

Aluminium material was used for the fabrication of the mold. The mold is $15.5 \mathrm{~cm}$ long with $3 \mathrm{~cm}$ wide cubes. The lock hole is $0.3 \mathrm{~cm}$ to allow the upper part of the mold to key in tightly into the lower part. A passage for excesses was built into the mold to allow over flow of excess materials. Fermented oven dried samples were molded into cubes which can be used as soup additives (Figure 3 \& Figure 4).

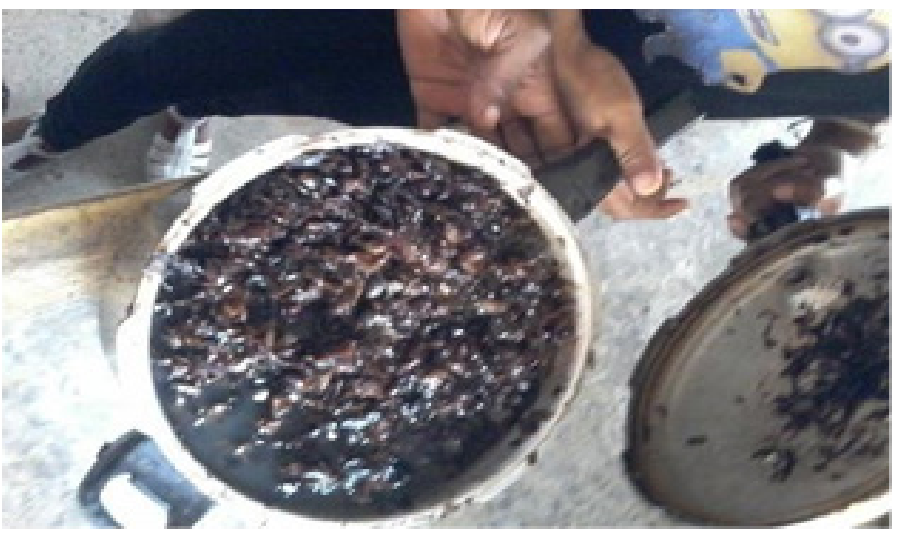

Figure I Boiled African locust seeds.

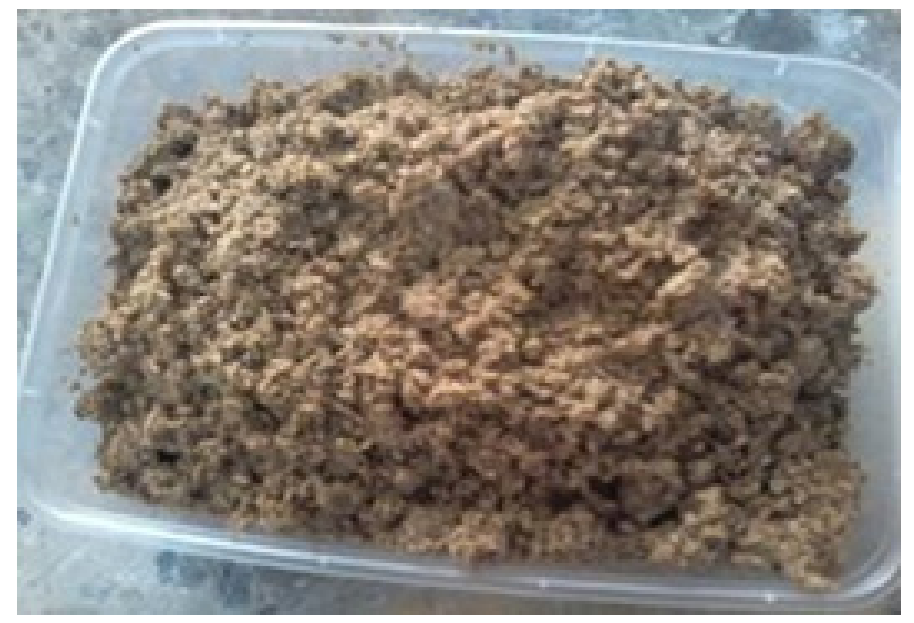

Figure 2 Processed African locust bean seeds. 


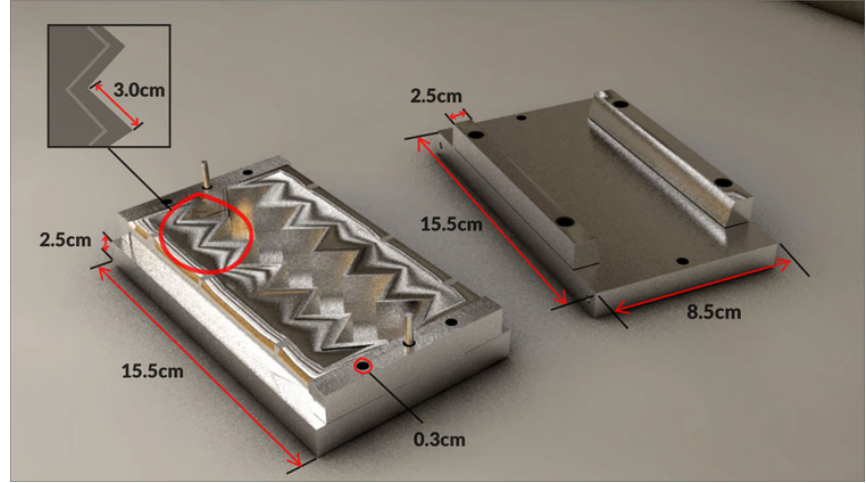

Figure 3 Dimension of the fabricated mold.

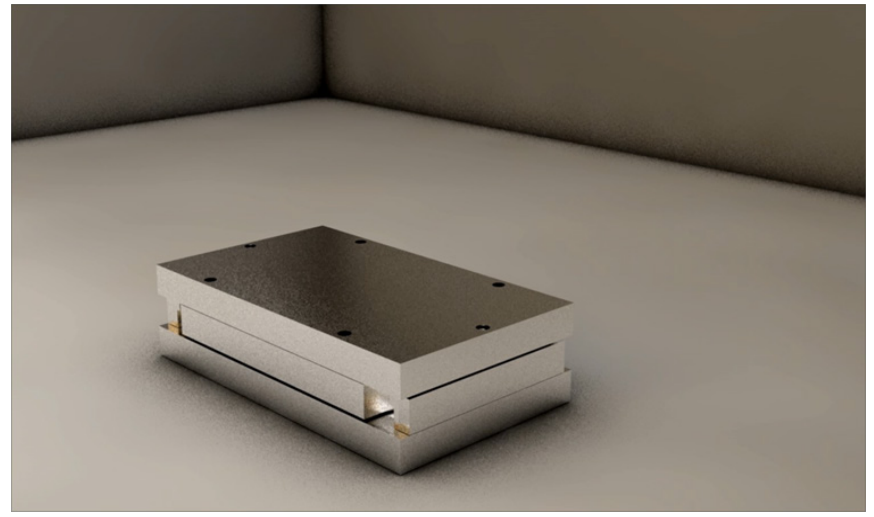

Figure 4 The mold.

\section{Conclusion}

Aluminium material is food friendly, hence it was chosen for the mold fabrication. It gave a good shape for the moulded samples [cubes]. Literature revealed that apart from various health benefit embedded in fermented African locust bean seed, is very rich in plant based protein, hence the cubes produced can be used as a substitute to meat or any other protein used in cooking soup. ${ }^{12,13,16-19}$

\section{Funding}

None.

\section{Acknowledgments}

I wish to use this medium to acknowledge Dr. Ojewumi M.E. for the supervision of my final year research project.

\section{Conflicts of interest}

Authors declares there is no conflicts of interest.

\section{References}

1. Ojewumi ME. Biological and chemical changes during the aerobic and anaerobic fermentation of African locust bean. International Journal of Chemistry Studies. 2018;2(2):25-30.

2. Modupe Elizabeth Ojewumi, Benjamen Eluagwule, Ayodeji A Ayoola, et al. Termiticidal Effects of African Locust Bean (Parkia Biglobosa) seed oil Extracts. International Journal of Current Research. 2017;9(7):5392953934.
3. Azokpota P, D Hounhouigan, M Nago. Microbiological and chemical changes during the fermentation of African locust bean (Parkia biglobosa) to produce afitin, iru and sonru, three traditional condiments produced in Benin. Int J Food Microbiol. 2006;107(3):304-309.

4. Gernah D, M Atolagbe, C Echegwo. Nutritional composition of the African locust bean (Parkia biglobosa) fruit pulp. Nigerian Food Journal. 2007;25(1):190-196.

5. Ojewumi M, J Omoleye, A Ajayi. Optimum fermentation temperature for the protein yield of parkia biglobosa seeds (Iyere). 2016.

6. Beaumont M. Flavouring composition prepared by fermentation with Bacillus spp. International journal of food microbiology. 2002;75(3):189196.

7. Teklehaimanot Z. Exploiting the potential of indigenous agroforestry trees: Parkia biglobosa and Vitellaria paradoxa in sub-Saharan Africa. Agroforestry Systems. 2004;61(1-3):207-220.

8. Uaboi Egbenni PO, Okolie PN, Sobande AO, et al. Identification of subdominant lactic acid bacteria in dawadawa (a soup condiment) and their evolution during laboratory-scale fermentation of Parkia biglobosa (African locust beans). African Journal of Biotechnology. 2009;8(25):7241-7248.

9. Ademola IT, Baiyewu RA, Adekunle EA, et al., An assessment into physical and proximate analysis of processed locust bean (Parkia biglobosa) preserved with common salt. Pak J Nutr. 2011;10(5):405-408.

10. AL Kolapo, TOS Popoola, MO Sanni, et al. Preservation of soybean daddawa condiment with dichloromethane extract of ginger. Research Journal of Microbiology. 2007;2(3):254-259.

11. Omafuvbe BO, Olumuyiwa SF, Bolanle AO, et al. Chemical and biochemical changes in African locust bean (Parkia biglobosa) and melon (Citrullus vulgaris) seeds during fermentation to condiments. Pak J Nutr. 2004;3(3):140-145.

12. Ojewumi M. Optimizing the conditions and processes for the production of protein nutrient from parkia biglobosa seeds. Covenant University, Nigeria. 2016.

13. Ojewumi M. Optimization of Fermentation Conditions for the Production of Protein Composition in Parkia biglobosa Seeds using Response Surface Methodology. International Journal of Applied Engineering Research. 2017;12(22):12852-12859.

14. ME Ojewumi, GO Kayode, JA Omoleye, et al., Statistical Optimization and Sensitivity Analysis of Rheological Models using Cassava starch. International Journal of Civil Engineering and Technology (IJCIET). 2019;10(1):623-639.

15. Ojewumi ME, Emetere M, Babatunde DE, et al. In Situ Bioremediation of Crude Petroleum Oil Polluted Soil Using Mathematical Experimentation. International Journal of Chemical Engineering. 2017;518476:1-11.

16. Ojewumi ME, Omoleye JA, Ayoola AA, et al. Effects of salting and drying on the deterioration rate of fermented parkia biglobosa seed. J Nutr Health Food Eng. 2018;8(1):37-41.

17. Ojewumi ME, Omoleye JA, Ayoola AA, et al. Evaluation of fermentation rate for the production of a protein based African seed condiment. Biotechnology. 2018.

18. Ojewumi ME, JA Omoleye, AA Ajayi. The Effect of Different Starter Cultures on the Protein Content in Fermented African Locust Bean (Parkia Biglobosa) Seeds. International Journal of Engineering Research \& Technology. 2016;5(4):249-255.

19. Ojewumi ME, James Omoleye, Moses Emetere, et al., Effect of various temperatures on the nutritional compositions of fermented African locust bean (Parkia biglobosa) seed. International Journal of Food Science and Nutrition. 2018;3(1):117-122. 
20. Ojewumi ME, AO Odubiyi, J Omoleye. Effect of Storage on Protein Composition of Fermented Soybean (Glycine Max) Seed by Bacillus Subtillis. Novel Techniques in C Nutrition and Food Science. 2018;2(4):1-

21. Ojewumi ME, J Omoleye, A Ajayi. The Study of the Effect of Moisture Content on the Biochemical Deterioration of Stored Fermented Parkia Biglobosa Seeds. Open Journal of Engineering Research and Technology. 2016;1(1):14-22.
22. Odunfa SA. Biochemical changes during production ofogiri, a fermented melon (Citrullus vulgaris Schrad) product. Plant Foods for Human Nutrition. 1983;32(1):11-18. 